\title{
Dynamics of Carbon 14 in soils: A review
}

\author{
C. Tamponnet \\ Institute of Radioprotection and Nuclear Safety, DEI/SECRE, CADARACHE, BP. 1, \\ 13108 Saint-Paul-lez-Durance Cedex, France, e-mail: christian.tamponnet@irsn.fr
}

\begin{abstract}
In terrestrial ecosystems, soil is the main interface between atmosphere, hydrosphere, lithosphere and biosphere. Its interactions with carbon cycle are primordial. Information about carbon 14 dynamics in soils is quite dispersed and an up-to-date status is therefore presented in this paper.

Carbon 14 dynamics in soils are governed by physical processes (soil structure, soil aggregation, soil erosion) chemical processes (sequestration by soil components either mineral or organic), and soil biological processes (soil microbes, soil fauna, soil biochemistry).

The relative importance of such processes varied remarkably among the various biomes (tropical forest, temperate forest, boreal forest, tropical savannah, temperate pastures, deserts, tundra, marshlands, agro ecosystems) encountered in the terrestrial ecosphere.

Moreover, application for a simplified modelling of carbon 14 dynamics in soils is proposed.
\end{abstract}

\section{INTRODUCTION}

The importance of carbon 14 of anthropic origin in the environment has been quite early a matter of concern for the authorities [1].

When the behaviour of carbon 14 in the environment is to be modelled, it is an absolute necessity to understand the biogeochemical cycles of carbon. One can distinguish indeed, a global cycle of carbon from different local cycles. As far as the biosphere is concerned, pedosphere is considered as a primordial exchange zone. Pedosphere, which will be named from now on as soils, is mainly located at the interface between atmosphere and lithosphere. Soil is a several meters depth-layer located at the surface of the terrestrial crust. In terrestrial ecosystems, soils are the support of all the biotic activities and they interact also with atmosphere, lithosphere, biosphere and hydrosphere.

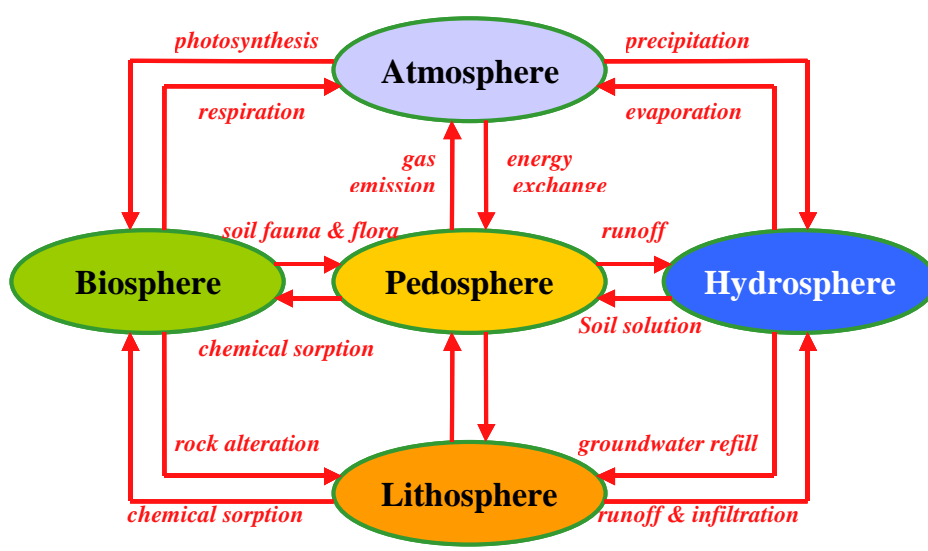

Figure 1. Soil interactions. 
Such interactions affect the biogeochemical cycles of the major chemical elements including the most important one: carbon. The complexity of the processes involved makes it hard to understand the carbon dynamics in soils. Only a good knowledge of the carbon dynamics in soils would allow a correct modelling of the accidental release of carbon 14 in soils by nuclear industry.

This is the goal of this paper using for that purpose the scientific knowledge acquired following the current effort to understand climate change (in particular the role of carbon dioxide as greenhouse effect agent and the potential role of soil as a carbon sink).

\section{BIOGEOCHEMICAL CYCLE OF CARBON IN SOILS}

\subsection{Introduction}

Carbon dioxide enters higher plants leaves via stomata. Yearly, $270 \mathrm{Gt}$ of carbon (one third of total atmospheric carbon dioxide) follow that step. Only one part of it is converted into carbohydrates:, namely the gross primary production (GPP $=120 \mathrm{Gt}$ of carbon per year). Half of it is incorporated into plant tissues, namely the net primary production (NPP $=60 \mathrm{Gt}$ of carbon per year). The other half is converted into carbon dioxide via the plant respiration namely the autotrophic respiration (see figure 2).

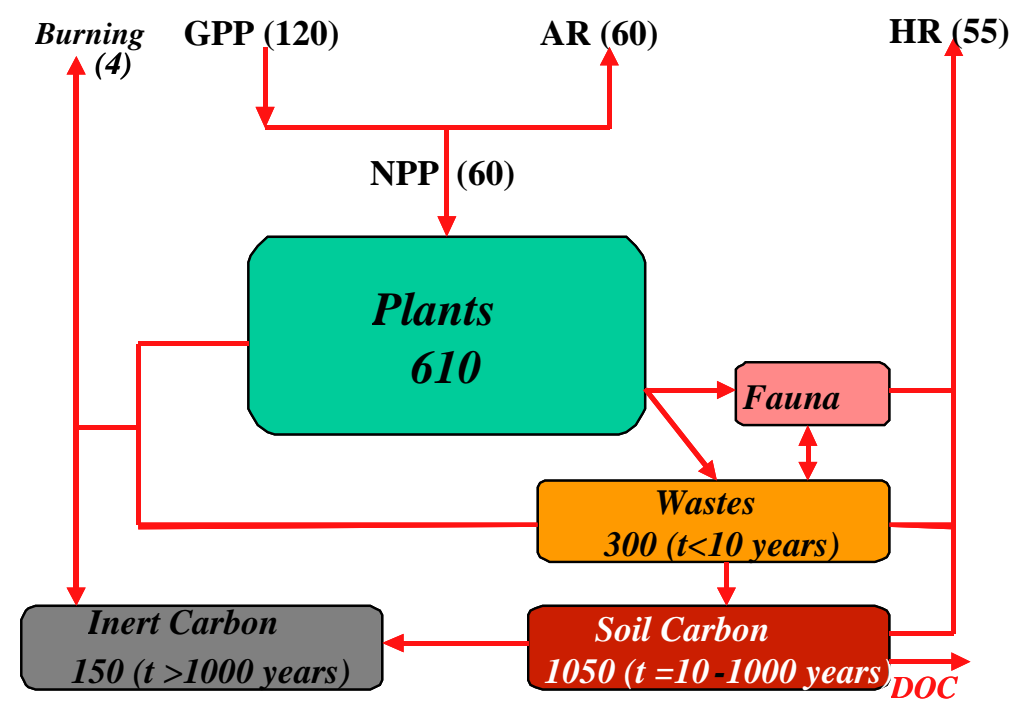

Figure 2. Carbon cycle in terrestrial ecosystems. GPP = Gross Primary Production, NPP = Net Primary Production; $\mathrm{AR}=$ autotrophic respiration, $\mathrm{HR}=$ heterotrophic respiration, $\mathrm{t}=$ mean duration of stock expressed as Gt of carbon, DOC = Dissolved Organic Carbon exported via leaching from [2-5].

Nearly all of the carbon incorporated in the plant tissues (NPP = 60 Gt of carbon) will return to the atmosphere as carbon dioxide either via the heterotrophic respiration ( $\mathrm{HR}=55 \mathrm{Gt}$ of carbon per year) i.e. the respiration of animals, bacteria and fungi, or via burning of natural and anthropic origin (4 Gt of carbon per year).

Nearly all the dead biomass will enter the wastes and soil organic matter pools. It is degraded through respiration at different rates according to the chemical composition of the dead biomass and the environment conditions (such as soil temperature and soil humidity).

Therefore, the total soil carbon and in the repartition of carbon between soil and vegetation will vary greatly according to the type of biomes (see table 1 ). 
Table 1. Estimated stocks of carbon in soils and vegetation in the different terrestrial biomes (from [6-7].

\begin{tabular}{|c|c|c|c|c|c|c|c|}
\hline \multirow[t]{2}{*}{ Biome } & \multirow[t]{2}{*}{$\begin{array}{c}\text { Area } \\
\text { (Gha) }\end{array}$} & \multicolumn{3}{|c|}{ Global Carbon Stocks (GtC) } & \multicolumn{2}{|c|}{$\begin{array}{c}\text { Carbon Density } \\
\quad\left(\mathrm{kgC.m^{-2 } )}\right.\end{array}$} & \multirow[t]{2}{*}{$\begin{array}{c}\text { NPP } \\
\left(\text { GtC.year }^{-1}\right)\end{array}$} \\
\hline & & Plants & Soils & Total & Plants & Soils & \\
\hline Tropical Forests & 1,75 & 340 & 213 & 553 & 19,4 & 12,2 & 21,9 \\
\hline Temperate Forests & 1,04 & 139 & 153 & 292 & 13,4 & 14,7 & 8,1 \\
\hline Boreal Forests & 1,37 & 57 & 338 & 395 & 4,2 & 24,7 & 2,6 \\
\hline Tropical Savannah & 2,76 & 79 & 247 & 326 & 2,9 & 9,0 & 14,9 \\
\hline Temperate Grasslands & 1,78 & 23 & 176 & 199 & 1,3 & 9,9 & 7,0 \\
\hline Deserts \& semi-deserts & 2,77 & 10 & 159 & 169 & 0,4 & 5,7 & 3,5 \\
\hline Tundra & 0,56 & 2 & 115 & 117 & 0,4 & 20,6 & 0,5 \\
\hline Wetlands & 0,35 & 15 & 225 & 240 & 4,3 & 64,3 & 4.3 \\
\hline Croplands & 1,35 & 4 & 165 & 169 & 0,3 & 12,2 & 4.1 \\
\hline Total or *means & 15,28 & 669 & 1792 & 2461 & $* 4,4$ & $* 11,7$ & 66,9 \\
\hline
\end{tabular}

\subsection{Various processes governing soil carbon}

There are 2 types of carbon stocks in soils: the Soil Organic Carbon (SOC) and the Soil Inorganic

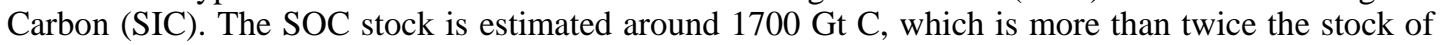
total atmospheric carbon (750 Gt C)a and three times the amount stored in living plants. The SIC stock is mainly found as carbonates in deserts and semi-deserts and therefore can be hardly estimated.

The pool of SOC is controlled by two fundamental processes, namely the NPP and the activity of decomposers and on a smaller scale by three other factors, namely fire, leaching and erosion (see figure 3 ).

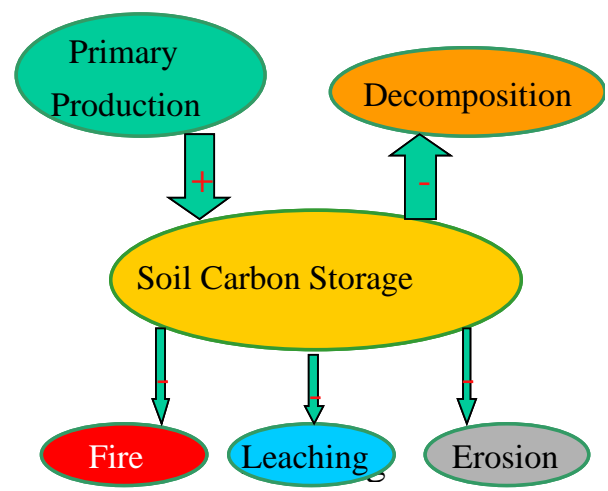

Figure 3. Diagram showing the major processes controlling the soil carbon storage from [8].

\subsection{Various pools of soil organic carbon}

Generally, one can distinguish four pools of soil organic carbon. The first pool can be associated with the fresh organic matter. This pool is the entrance pathway of soil organic carbon from the net primary production (about $1 \mathrm{Gt} C$ per year). Two types of processes are affecting this pool: decomposition or primary mineralization (i.e. heterotrophic respiration) and humus formation (transforming fresh organic matter into humus).

Such processes are under the control of microbes whose biomass corresponds to the second pool of soil organic carbon.

The third pool can be associated with humus. This pool is directly affected by processes globally called secondary mineralisation. Such processes are transforming humus into carbon dioxide (i.e. heterotrophic respiration at a much slower rates than the one affecting the fresh organic matter) and inert carbon, which is the fourth pool of soil organic carbon. 


\subsection{Parameters controlling soil organic carbon}

In closed ecosystems, atmospheric carbon dioxide concentration is controlled by soil respiration (heterotrophic respiration), light intensity (affecting the Net primary production) and the acido-basic equilibrium of soil [9].

Indeed, dead biomass enters soil organic matter pools and is degraded via heterotrophic respiration. Such process is controlled by the chemical composition of this dead biomass and by the environment factors such as temperature and soil humidity.

More precisely, soil organic carbon is controlled by the biochemical composition of the fresh organic matter, but also by the percentage of organic matter that can be found dissolved in the soil solution. Indeed, the mineralisation processes much more easily affect such dissolved Organic Matter (DOM). One can distinguish two pools of DOC (dissolved organic carbon) characterised by very short (2-5 days) and long (0.2-8.6 years) half-lives [10].

Soil temperatures can affect soil organic carbon pools. Indeed, in artic soils, there is a decoupling of carbon dioxide production and emission [11].

Mineral composition of soil can affect secondary mineralisation processes vs chemical and physical stabilisation of organic carbon [12].

Change of dominant plant species can modify soil carbon cycle but on a short period of time [13].

\section{MODELLING CARBON 14 DYNAMICS IN SOILS}

\subsection{Introduction}

Modelling and understanding of the soil carbon cycle processes is facing large uncertainties about the size and the mean residence time of the various pools of soil carbon. These uncertainties come from the lack of standardised measurement methods and from the lack of knowledge on the exact mechanisms of soil carbon dynamics [8].

First models estimating the actual and future concentrations of carbon 14 in our environment have been published in the early seventies [14-15]. These were multiple-box models whose carbon 14 fluxes were described as first order linear differential equations. In such models, soil was represented as one compartment.

\subsection{The Rothamsted model}

The first model dealing specifically with the dynamics of soil carbon appeared in the late seventies: the Rothamsted Model [16]. This model is based on data collected from open field experiments in the Rothamsted experimental station. It is exemplified in the Figure 4.

Since its publication, this model has been validated with numerous experimental data. It predicts that from an annual deposit of 1 ton of carbon per hectare, the soil will contain after 10,000 years, under stationary equilibrium conditions, the followings:

0.01 ton $\mathrm{C}$ as decomposable plant material (DPM)

0.47 ton $\mathrm{C}$ as resistant plant material (RPM)

0.28 ton $\mathrm{C}$ as soil biomass (BIO)

11.3 ton $\mathrm{C}$ as physically -stabilised organic matter (POM)

12.2 ton $\mathrm{C}$ as chemically-stabilised organic matter (COM) 


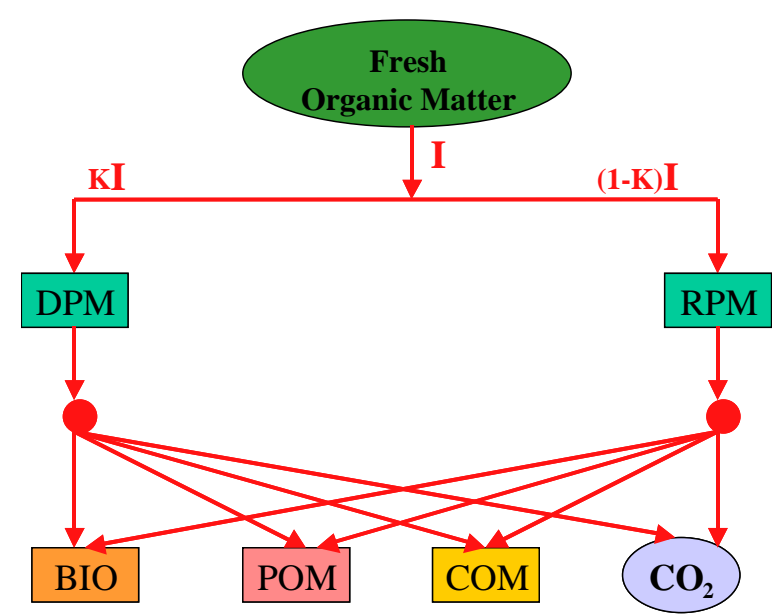

Figure 4. Carbon fluxes in the Rothamsted model. With DPM = decomposable plant materials (half-live $=.165 \mathrm{yr}$ ); $\mathrm{RPM}=$ resistant plant material (half-live $=2.31 \mathrm{yr}$ ); $\mathrm{BIO}=$ soil biomass (half-live = $1.69 \mathrm{yr}$ ); $\mathrm{POM}=$ physically-stabilised organic matter ((half-live $=49.5 \mathrm{yr})$; COM = chemically-stabilised organic matter ((half-live = $1980 \mathrm{yr})$.

\subsection{The other models}

In the Van Veen and Paul model, the DPM is divided into 2 pools: the easily decomposable compounds and the (hemi) cellulose, the RPM being related to lignin [17]. Degradation rates are considered as independent from the soil biomass (first order kinetics).

The Mc Gill and Cole model is based on the fact that carbon and nitrogen are stabilised and mineralised together via biological processes [18].

Following Mc Gill and Cole model, many models appeared taking intro account the biogeochemical cycle of essential elements such as carbon not only in soils but also in plants growing on these soils [19-26]. For instance, the DNDC model incorporates both the carbon and nitrogen cycles [27-28].

A bibliographic analysis shows us that the most used models are Rothamsted model [16] and CENTURY model [19].

\subsection{A simplified model of soil carbon dynamics}

For estimating carbon 14 release by soil after an accidental atmospheric contamination, a simplified model is proposed with only 3 pools of carbon in soil (namely the fresh organic matter FOM, soil biomass BIO, and humus HUM), an input (primary production) and an output (release of carbon dioxide in the air $\mathrm{CO} 2$ ). This model is experessed by the following equations:

$$
\begin{gathered}
\frac{\partial\left[{ }^{14} C\right]_{C O 2}}{\partial t}=k_{M} \cdot\left[{ }^{14} C\right]_{M O F} \\
\frac{\partial\left[{ }^{14} C\right]_{M O F}}{\partial t}=-k_{M} \cdot\left[{ }^{14} C\right]_{M O F}+f_{\text {in }}\left(\left[{ }^{14} C\right]_{P P}, t\right)
\end{gathered}
$$

with:

$\left[{ }^{14} \mathrm{C}\right]_{M O F}$ in fresh organic matter (Bq.m $\left.{ }^{-2}\right)$,

$\left[{ }^{14} \mathrm{C}\right]_{\mathrm{CO} 2}$ carbon 14 concentration released in the air as carbon dioxide (Bq. $\left.\mathrm{m}^{-2}\right)$. 
$\left[{ }^{14} \mathrm{C}\right]_{I P P}$ carbon 14 concentration in input from primary production (Bq. $\left.\mathrm{m}^{-2}\right)$.

$k_{M}$ transfer rate from fresh organic matter to carbon dioxide (temps $\left.{ }^{-1}\right)$.

$f_{\text {in }}$ input function from primary production to fresh organic matter $\left(\mathrm{Bq} \cdot \mathrm{m}^{-2}\right)$.

\section{Acknowledgments}

This activity has been partly funded by Electricité de France.

\section{References}

[1] Killough G.G. and Till J.E. Nuclear Safety 19 (1978) 602-622.

[2] Schimel D.S., Braswell B.H., Holland E.A., McKeown K., Ojima D.S., Painter T.H., Parton W.J. and Townsend A.R., Global Biogeochemical Cycles 8 (1994) 279-293.

[3] Batjes N.H., European J. of Soil Science 47 (1996) 151-163.

[4] Falloon P., Smith P., Coleman K. and Marshall S., Soil Biology and Biochemistry 30 (1998) 1207-1211.

[5] Scholes M. and Andreae M.O. Ambio 29 (2000) 23-29.

[6] Atjay G.L., Ketner P., and Duvigneaud P. "Terrestrial primary production and phytomass" in The Global Carbon Cycle, Bolin B., Degens E.T., Kempe S. a,d Ketner P., Eds, (John Wiley and sons,Chichester, 1979) pp. 129-181.

[7] Mooney H., Roy J. and Saugier B. Terrestrial Global productivity: past, present and future (Academic Press, San Diego, 2001).

[8] Wang Y. and Hsieh Y., Chemosphere 49 (2002) 791-804.

[9] Engel V.CX. and Odum H.T. Ecological Engineering 13 (1999) 107-134.

[10] Kalbitz K., Schmerwitz J., Schwesig D. and Matzner E., Geoderma 113 (2003) 273-291.

[11] Elberling B. and Brandt K.K. Soil Biology and Biochemistry 35 (2003) 263-272.

[12] Guggenberger G. and Kaiser K. Geoderma 133 (2003) 293-310.

[13] Chen J. and Stark J.M. Soil Biology and Biochemistry 32 (2000) 47-57.

[14] Iwakura T. Hoken-Butsuri 7 (1972) 7-14.

[15] Venkatavaradan V.S. Proc. Ind. Acad Sci. Sect A 79 (1974) 256-268.

[16] Jenkinson D.S. and Rayner J.H. Soil Science 123 (1977) 298-305.

[17] Van Veen J.A. and Paul E.A. Can J Soil Sci 61 (1981) 185-201.

[18] McGill W.B. and Cole C.V. Geoderma 26 (1981) 267-286.

[19] Parshotam A., Saggar S., Tate K., and Parfitt R. Environment International 27 (2001) 111-119.

[20] Gabrielle B., Mary B., Roche R., Smith P., Gosse and G. Eur. J. of Agronomy 18 (2002) 107-120.

[21] Bruun S., Christensen B.T., Hansen E.M., Magid J. and Jensen L.S. Soil Biology and Biochemistry 35 (2003) 67-76.

[22] Motavalli P.P., Palm C.A., Parton W.J., Elliott E.T. and Frey S.D. Soil Biology and Biochemistry 26 (1994) 935-944.

[23] Martin P. Environmental Science and Policy 1 (1998) 87-97.

[24] Churkina G., Tenhunen J., Thornton P., Falge E.M., Elbers J.A., Erhard M., Grunwald T., Kowalski A.S., Rannik U. and Sprinz D. Ecosystems 6 (2003) 168-184.

[25] Hill M.J. Environmental Modelling and Software 18 (2003) 899-913.

[26] Shevtsova L., Romanenkov V., Sirotenko O., Smith P., Smith J.U., Leech P., Kanzyvaa S. and Rodionova V. Geoderma 116 (2003) 165-189.

[27] Li C., Frolking S. and Harriss R. Global Biogeochemical cycles 8 (1994) 237-254.

[28] Zhang Y., Li C., Zhou X. and Moore III B. Ecological Modelling 151 (2002) 75-108. 